Giddens' artikler er skrevet på et tidspunkt, hvor der endnu var håb. Det kunne have været interessant at have fået hans vurderinger af situationen $\mathrm{i}$ dagens England.

Vel, bogen er let læst, den formidler et nogenlunde overblik over Giddens' modernitetsforståelse, men kommer sjældent i dybden (hvis der er en sådan). Giddens fremstår som sympatisk. For folk, som mere indgående har beskæftiget sig med Giddens, giver bogen, bortset fra de biografiske fortællinger, ikke meget nyt. Bogen er godt oversat af Stefan Hermann.

Hans-Jorgen Schanz

\section{Frege på dansk}

Friedrich Ludwig Gottlob Frege: Filosofiens, sprogets og matematikkens grundlag, tekstudvalg $i$ dansk oversattelse ved Peer F. Bundgaard, indledning ved Lars Binderup, Forlaget Philosophia, 2002, 265 sider.

Så kom den endelig! En oversættelse af Freges (1848-1925) vigtigste skrifter til dansk, inklusive en (modig) oversættelse af dennes banebrydende værk om aritmetikkens grundlag fra 1884. Oversættelsen er glimrende, den fyldige indledning aldrig mindre end brugbar og forlaget har grund til at gratulere sig selv med, at de har udsendt denne i høj grad anvendelige publikation.

De filosofisk mest vægtige skrifter er alle med. Oven i købet får vi i indledningen kendskab til et afgørende brev til Husserl om Freges 'system', hvori vi præsenteres for sondringen imellem syntaktiske kategorier, meninger og betydninger (semantiske værdier, med Dummetts udtryk) for forskellige typer af udtryk. Den moderne logiks grundlæggelse ved Frege fremlægges klart. Freges bidrag til at muliggøre og igangsætte moderne sprogfilosofi lægges for dagen på eksemplarisk måde. Kommentarerne til hans overvejelser over aritmetikken i vid forstand er lidt mere kortfattede, men stadig udmærkede, så langt de rækker. Hvad indledningen angår, kan ingen rimelig person indvende noget alvorligt imod en tekst af denne længde og med den tilsigtede intentionsdybde. Vi får især præsenteret Freges filosofiske semantik og grundlæggelse af moderne sprogfilosofi på en rimelig måde. Hans krav på dermed at være ophavsmand til såkaldt analytisk filosofi gøres godt. Hans matematikfilosofi fremstilles (med rette) mere kortfattet; og fundamentet af moderne logik fremstilles med markering af hovedpunkterne (hvor den afgørende pointe ligger ved behandlingen af essentielt iterativ kvantificering). Lad være, at Binderup tilsyneladende er iblandt dem, der mener, at den nyligt afdøde amerikanske filosof med det fantasti- 
ske navn Willard Van Orman Quine hed von eller van Quine. Dette har i tidens løb givet anledning til mange overvejelser, især i Europa. Men hvis Quine var von eller van noget, må det enten være van Harvard (hvor han hovedsageligt arbejdede) eller von Akron, Ohio (hvor han fødtes).

Der kan naturligvis ikke være tale om på dette sted at anmelde Frege. Hovedparten af det følgende forholder sig derfor til Lars Binderups udmærkede indledning; til Frege i bedste fald kun indirekte. Freges afgørende bidrag til logik, semantik og matematikkens filosofi fremstilles og diskuteres temmelig klart og instruktivt. Man kan måske savne en opfølgning på Freges hovedpunkt i 'Über Sinn und Bedeutung' (Om mening og betydning), som er redningen af kompositionalitetsprincippet for både semantisk værdi og mening ved at introducere stærk intensionalisme. Dette er senere blevet udbygget på forskellig måde af bl.a. Carnap, Church, Kripke, D. Lewis og Montague. Teknisk set virker dette, temmelig langt. Der kan være filosofiske problemer med at redegøre for intensionelle objekter; men det er måske her især både filosoffer, teoretiske lingvister af forskellig type og mange andre griber fat. Begrebsapparaturet er økonomisk og frugtbart. Tag fejlslutningen:

\section{(1) Jesper tror, at Kepler døde i armod.}

(2) Kepler er identisk med opdage ren af elliptiske planetbaner.

(3) Derfor: Jesper tror, at opdage ren af elliptiske planetbaner døde $\mathrm{i}$ armod.

Måske ikke; for måske aner Jesper intet om Kepler. Men som Frege siger, er fejlen forklarlig uden brud på Leibniz's Lov for substitution af identiske størrelse salva veritate. For der er tale om en indirekte kontekst for 'Kepler' i (1). Ordet refererer derfor her til meningen med ordet Kepler i direkte kontekster. Derimod refererer det samme ord i (2) til Kepler selv, altså den direkte semantiske værdi (betydningen) af navnet. Følgelig kan sammenbruddet af slutningen $i$ sådanne (indirekte, modale, intensionelle) kontekster ikke undre. Og Leibniz's Lov og kompositionalitet iøvrigt kan fastholdes: Udtryk med samme semantiske værdi kan universelt substitueres salva veritate. Omkostningen er, at der findes intensionelle størrelser ('meninger') i den stærke forstand, at der kan refereres til disse. Ekstensionalister (Quine, Davidson og utallige andre) bryder sig ikke om dette; og der er i det mindste en metodologisk pointe $i$ at forsøge at klare sig uden eksplicit reference til intensionelle størrelser. Men Freges teori er stærk, økonomisk og levedygtig. Binderup siger noget herom; men eftersom dette er hele pointen $\mathrm{i}$ artiklen, siger han måske lovlig lidt.

En angivelig vanskelighed dukker op (p. 33). Hvad gør vi fregeansk 
ved flg., tilsyneladende gyldige (?), $\mathrm{Og}$ dette er en rimelig gengivelse argument:

(1) Jesper tror, at Jorden er rund.

(2) Jorden er rund

(3) Derfor: Jesper tror noget, som er sandt.

Skønt dette argument uden tvivl er intuitivt gyldigt, har Frege problemer med at redegøre for denne gyldighed. For der ækvivokeres. I (2) er den semantiske værdi af sætningen Det Sande. Den samme sætning optræder i (1) i en indirekte kontekst, hvor den derfor ifølge Frege betegner meningen af den direkte brugte sætning 'Jorden er rund'. Følgelig opstår spørgsmålet om en substitution ikke i: 'Jesper tror $x$ og $x$ er sand(t)'.

Vi har at gøre med en 2. ordens-slutning. Men dette burde ikke stoppe en fregeaner. Det specifikke problem er angiveligt de gennem argumentet vekslende betydninger af 'Jorden er rund'. Men Frege tror på ækvivalenstesen for sandhed:

(ÆS) Det er sandt at p, hvis og kun hvis p.

Fra (2) følger derfor:

(2') Det er sandt, at Jorden er rund. Men fra (1) og (2’) følger vel:

(3’) Der findes en sætningsmening p, således at Jesper tror at $\mathrm{p}$ og det er sandt at $\mathrm{p}$. af meningen af (3). Så fregeansk er der ikke noget umiddelbart problem. Noget andet er, at (ÆS) er dybt problematisk. Dette mente imidlertid ikke Frege. Han ville ikke have kunnet vide, hvad de reelle problemer er, eftersom de først blev udpeget af Tarski og - indirekte - Gödel i begyndelsen af 1930'erne.

Det er kun med visse forbehold rigtigt (p. 34), at Dummett erklærer sig uenig i den fregeanske tanke, at en sprogbrugers forståelse af den deklarativt udtrykte tanke at $p$ består $i$ kendskab til sandhedsbetingelsen af p. Hele dette område er underbelyst $i$ indledningen; men samtidig rejses spørgsmålet. Den dummettianske anti-realist vil typisk hævde, at sætningsforståelse består i kendskab til sætningens hævdelsesbetingelse, snarere end i kendskab til dens muligvis verifikations-transcendente sandhedsbetingelse. Men Dummett er helt klar over, at hans anti-realist ikke behøver at bestride holdbarheden af sandhedsbetingelsessemantikken. Denne kan imidlertid ikke være den originære redegørelse for sprogforståelse. For spørgsmålet opstår da, hvad vi skal forstå ved sandhed. Det er ganske afgørende at indse dette, da man i modsat fald forledes til at tro, at en davidsoniansk meningsteori (sandhedsbetingelser via Tarskis apparatur) a priori er udelukket for en anti-realist. Dette er ikke tilfældet. Tolk 'sandhed' som 
'hævdelighed i det lange løb' og benyt intuitionistisk logik i metasproget. Det hele går pænt igennem (så længe sandhedsværdierne er monotone). Spørgsmålet er imidlertid, om resultatet er en sigende karakteristik af sproglig mening.

Binderup diskuterer kort (p. 34) tesen om, at navne har mening. Diskussionen kommer afsted på en skæv tone. Frege tilslutter sig ikke uden videre den russellianske idé om, at navne i dagligsproget er implicitte bestemte beskrivelser. Dette kan være sandt om mange navne men gælder ikke generelt. Alle navne har derimod tilknyttet til sig genidentifikationsbetingelser, som brugeren af navnet må kende som betingelse for, at han kan tilskrives viden om navnets rette anvendelse - mening. Så hvis brugeren af navnet præsenteres for navnets bærer, må brugeren være $\mathrm{i}$ stand til at indse, at her er jo netop det, hvorom han taler. Desuden angriber Kripke ikke direkte den idé, at navne overhovedet har en mening. Kripke interesserer sig ikke for navnes eller andre udtryks mening. I Naming and Necessity og tilknyttede skrifter går hans spørgsmål udelukkende på, hvorledes betydningen af udtrykkene fastsættes eller fikseres. Og, påpeger han, denne fiksering behøver ikke at ske med deskriptive eller repræsentative midler. Men det kan den. Derfor er det galt at udelukke, at bestemte beskrivelser kan være, hvad Kripke kalder rigide designatorer.
Men Frege og Kripke er klart uenige om, hvad en sprogbruger må vide, hvis han har fuld forståelse af brugen af et navneudtryk. Tag navnet 'Oxford'. Som Frege ser det, kan en person, som ikke genkender spirene på Magdalen College og Christ Church, St. Johns og Balliols arkitektonisk indifferente konturer, omridset af det bundløst frastødende Randolph Hotel med røvballegardiner og for dyre fødevarer og (ubestemt) flere karakteristiske træk ved Oxford, når han sættes i land på High Street, ikke tilskrives kendskab til brugen af navnet 'Oxford' (Hvis noget af de nævnte herligheder er blevet nedrevet $\mathrm{i}$ mit efterhånden lange fravær fra Oxford, bedes læseren indsætte nye træk efter behov). Dette mener ikke Kripke og andre tilhængere af den såkaldt kausale navneteori. Her kan en person, $\mathrm{X}$, meget vel vide, at han befinder sig i Oxford, alene fordi nogen engang kaldte dette kompleks af bygninger 'Oxford' og gennem avl og indlæring lod ordets brug gå videre gennem senere generationer til X. Men X kan ikke identificere noget i øvrigt genkendeligt træk ved byen, selv når han plantes midt på High Street. Begge synspunkter er åbenlyst $i$ umiddelbare vanskeligheder. Frege har en tendens til at overdrive den til forståelsen af et navn fornødne identifikatoriske sagkundskab. Kripke tillader os til gengæld at forstå navne pr. vikar. Det er dette, som er kernen i striden om, hvorvidt navne har mening. Binderup har ret $i$, at 
stridighederne endnu er uløste. De gælder endog andre ordklasser end navneudtryk. Måske havde G. Evans i Varieties of Reference noget nær det rette bud på en løsning: Ords brug institueres og transmitteres ved fortsat brug kulturelt. Så vidt har Kripke næsten ret. Men ingen, som ikke tager del i den levende vedligeholdelse af brugen af ordet, kan tilskrives forståelse af det. Og derfor har Frege fat i noget. Men det ville være patetisk at foregive, at vi hermed kan løse grænsestridighederne.

Mere kunne nok være sagt $\mathrm{i}$ indledningen om Freges understregning af, at negation hører til tankeinholdet, snarere end til talehandlingsaspektet ved en 'negativ' ytring (pp. 35-37), fx. 'Lars elsker ikke Steen'. Det er utvivlsomt korrekt (som senere underbygget af bl.a. Geach og Dummett), at man næppe ellers kan få god mening i vor logiske slutningspraksis. Men i Freges argumentation indgår en på dette punkt overflødig tilslutning til bivalensprincippet:

(BIV) Enhver velformet deklarativ sætning er enten skarpt sand eller skarpt falsk.

Derfor er det relativt trivielt, at dobbeltnegationselimination er en gyldig slutningsregel overalt. Men dette sidste er jo netop kontroversielt; og til dels uafhængigt heraf har bl.a. Huw Price og P. Milne argumenteret for, at der findes sui generis benægtelser til forskel fra hævdelser af negationer. Diskussionen pågår stadig, endnu en gang med deltagelse af Dummett.

Lars Binderups diskussion af tankers objektivitet er kort og relativt klar (pp. 37-41). Frege mente åbenbart, at den med en sætning udtrykte tanke er offentlig. Der må følgelig være i det mindste kvalitativ identitet imellem de tanker, Binderup udtrykker, og dem jeg ved læsningen forstår. Men Frege objektiverer disse tanker i det yderligere skridt, som vel består i en påstand om, at kvalitativt identiske tanker nødvendigvis er numerisk identiske. Lidt som visse skolastikere hævdede, at enhver engel udgør en egen art. Denne meningsplatonisme er selvsagt tvivlsom. Først og fremmest er den formentlig i sidste ende vanskeligt forenelig med det offentlighedsprincip for mening, som argumentationen tager udgangspunkt i. Men det er ikke let at se, hvorfor indeksikalers tilstedeværelse $\mathrm{i}$ sætninger (med den tilhørende sondring imellem sætningsmening og den med sætningen, som brugt ved en bestemt lejlighed, udtrykte tanke) skulle udgøre en fare for offentligheden af den kommunikerede tanke. Hvis Lars Binderup oprigtigt ytrer: 'Jeg tænker', er andre vel nok på det rene med, hvem han hævder tankevirksomheden tilkommer. Der opstår kun et problem for offentlig kommunikerbarhed, hvis man har forvirrede ideer om jeget (nuet, heret, detteheden, etc.), måske i hegeliansk stil. 
Der er ej heller nogen iøjnefaldende vanskelighed i, at Frege på den ene side behandler Det Sande som den semantiske værdi af deklarative sætninger og på den anden side sandhed som en (udefinerbar) egenskab ved sætninger (pp. 41-42). Det Sande er ganske vist et objekt og derfor ikke en egenskab - et begreb i Freges jargon. Men der er ingen modstrid i, at en sætning har en egenskab (sand) i kraft af virkelighedens beskaffenhed og at den tilskrives den semantiske værdi Det Sande som et resultat af sætningsmening og virkelighed. Der ville kun være et problem, hvis semantisk værdi og egenskab kunne udvise diskrepans; men hvorledes skulle dette kunne ske? Måske skyldes det indbildte problem her en manglende forståelse af, at semantiske værdier er i høj grad teoretiske størrelser. De indføres især for at muliggøre en redegørelse for sprogets kompositionalitet. Man kan til nød kritisere Frege for også her at interpretere sine tekniske termini lovligt realistisk.

Et tilbagevendende problem er indlederens karakteristik af Freges logicististe program for aritmetikken (i bred forstand). Vi får at vide, at al aritmetik ifølge dette program kan baseres på logik og analytiske definitioner (undertiden blot: definitioner) af de primitive ord. Og derfor er aritmetik logik. Men det er klart, at de definitoriske midler må begrænses en del, hvis dette resultat skal følge. I modsat fald er det en logisk/aritmetisk sandhed, at ungkarle er ugifte. Frege selv ønsker da også at begrænse definitionsmidlerne i definitionerne af aritmetiske udtryk til såkaldt 'logiske' begreber. Det er ikke godt at vide, hvad dette betyder. Reelt følte han sig fri til at benytte alle udtryk fra logik og mængdelæren i sine definitioner. Dette er den (trivielle) grund til, at hans reduktion af aritmetik til logik brød sammen. Imidlertid lykkedes det ham vidtgående at gennemføre reduktionen af aritmetik til mængdelære. Det er værd at hæfte sig ved, at dette er standardstof i enhver lærebog om mængdelære i dag. Aritmetik (og megen anden matematik) er indlejret $i$ en passende mængdelære. Hvad han ikke havde held til, var at gennemføre reduktionen af aritmetikken til noget simplere ('logik'). Hans begrundelsesprogram virkede derfor ikke. Men det ville bevisbarligt intet program af denne type kunne (Gödels første ukomplethedssætning, 1931).

Problemet omkring de i definitioner tilladelige midler er langtfra uskyldigt. Binderup formulerer oftest det logicistiske program i forlængelse af C. Wright og B. Hales neo-fregeanske karakteristik, ifølge hvilken det skulle gå ud på blot at påvise, at aritmetikken er analytisk (og derfor) a priori. Dette er i sig selv et vigtigt resultat, hvis det holder. Men det er ikke tilstrækkeligt for Freges oprindelige mål. Han ville vise, at aritmetikken følger af uomgxngelige love for 
tanken i det hele taget, d.v.s. logikken. Som især Dummett og G. Boolos har forsøgt at godtgøre, er det snyd at inkludere (en - håber vi - konsistent udgave af) mængdelæren i logikken i denne forstand. Eller omvendt: Hvis mængdelære virkelig er 2. ordens-logik, da er sidstnævnte i virkeligheden ikke logik i den intenderede forstand.

Binderup har godt fat i, at Frege trods sin virulente og effektive kritik af Kants opfattelse af aritmetikken som syntetisk a priori - vel en udvidelse og del af hans kritik af psykologismen i meningsteorien i almindelighed - på bunden tænkte inden for en overordnet kantiansk ramme. Det er faktisk slående, hvorledes grundlæggerne af de tre hovedretninger i moderne filosofi om matematikken, Hilbert, Brouwer og Frege, på forskellig måde alle var dybt influerede af kantianske tankegange. Det har formentlig i hine dage været umuligt at være andet, $\mathrm{i}$ det mindste i Europa.

Det er nødvendigt at påtale forordet (ved Steen Brock og Ejvind Hansen) til denne ellers prisværdige publikation. Forordet (og pressemeddelelsen ved de samme redaktører) minder på mange måder om en overstadig anbefalelsesskrivelse til bevilgende myndigheder $i$ anprisning af genstanden for værket, som mestendels tillige er dets forfatter. Frege klarer sig nok uden. Desuden er der tale om både falsk (og unødvendig) aktualisering og deciderede fejl. Det er fx. ikke tilfældet, at Dummetts 1967-artikel om Frege første gang publiceredes i Encyclopedia Britannica. Den udkom derimod i P. Edwards (red.): The Encyclopedia of Philosophy. Det er ej heller let at indse, hvordan Frege ved sin død i 1925 kunne have influeret 'kredsen omkring Hugo Dingler (den senere såkaldte Erlanger-skole med dens konstruktivistiske videnskabsteori)' (p. 7). Dingler arbejdede i München og Darmstadt; grundlæggeren af Erlanger-skolen, Paul Lorenzen, var 10 år gammel, da Frege døde; og Erlanger-skolen opstod naturnødvendigt en del år senere - ganske vist under inspiration af både Dingler og - mere specifikt - Frege (især abstraktionsteorien). At mene, at Frege er relevant for moderne computervidenskab, svarer til at påstå, at Kepler er relevant for moderne astronomi (her taler dog Binderup, hvis første side lider af de samme skavanker). Korrekt, men på en eller anden måde uden balance. Det er ligeledes tvivlsomt, om 'Frege-receptionen' først lige er begyndt som forordets redaktionelle forfattere vil have. Efter navnlig J.L. Austins oversættelse af dele af Frege til engelsk og Dummetts monumentale arbejder om Frege er der tygget så meget drøv på dennes doktriner, at videre beskæftigelse med sagerne er en meget akademisk forestilling - eller, som i dette tilfælde, evt. et spørgsmål om udmærket popularisering egnet til både undervisning og selvstudium. Men Frege-receptionen har da rigtignok hidtil været ufortjent 
ringe i Danmark. Forhåbentlig kan det foreliggende værk bidrage til at bedre på denne beklagelsesværdige situation.

Værket savner indeks. Og litteraturlisten har mærkeligt nok ikke $\mathrm{H}$. Noonans bog om Frege fra 2001 (som vist da udkom i december 2000) med, skønt der henvises til denne $\mathrm{i}$ indledningen (pp. 11 og 21). I øvrigt har man ikke ved kompilationen gjort sig den ulejlighed at opstøve tekster på dansk (eller nordisk) om Frege. Vi bliver præsenteret for pligtlisten. Denne er ganske rimelig, men har vel noget begrænset relevans for læsere af netop en oversættelse til dansk af Frege.

Lad mig imidlertid understrege, at der er tale om en højst tiltrængt og overordentlig anvendelig publikation. Måtte flere berige sig ved læsning af denne uforligneligt klarttænkende og banebrydende filosof! Forlag, redaktører, oversætter og indleder fortjener vore varmeste tanker. Det er i Freges ånd at offentliggøre $\mathrm{i}$ det mindste nogle af disse.

Stig Alstrup Rasmussen

\section{Det filosofiske liv}

\author{
Finn Thorbjorn Hansen, Det filosofiske liv, \\ Gyldendal 2002, 483 sider, 378 kr.
}

Det foreliggende værk er et forsøg på, som det hedder $\mathrm{i}$ indledningen, "at bygge bro mellem på den ene side idehistoriske og filosofiske indsigter og viden og på den anden side udvikling af pædagogisk teori og praksis." Den ene side, afhandlingens første del, består af læsninger af Foucault, Rorty, Kierkegaard og mange flere, hvilket ligesom de mange læsninger på den anden side, afhandlingens anden del, optager uforholdsmæssigt meget plads. Læsningerne af de tre filosoffer, som jeg har fremhævet, er stærke, men har en tendens til at gentage og variere det allerede sagte. Det skyldes, at bogen er diskuterende og skrider frem i modstillinger: han er enig i, men på den anden side uenig i..., det betyder ikke det og det, men snarere... I denne stil bliver alle indsigter bundet op på positioner - og det skal guderne vide, at denne bog præsenterer et sandt overflødighedshorn af standpunkter - og de gennemspilles igen og igen. Ofte knyttes forbindelserne hurtigt med et "jævnfør" eller "det er ligesom", hvilket ville være på sin plads, hvis det medførte en uddybning af begreberne. Men det er som om positionerne nogle gange er vigtigere end sagen, som jo var det filosofiske liv med tænkningen og dannelsen i centrum. Tag side $180 \mathrm{og}$ side 213, der hver indeholder mere 